\title{
The Electoral College: A Constitutional Needle in a Political Hay Stack
}

\author{
Anna M. $\operatorname{Cox}^{1}$ \\ ${ }^{1}$ M.A. in Political Science in American Government with graduate certificate in Ancient/Classical History from \\ American Public University, United States \\ Correspondence: Anna M. Cox, M.A. in Political Science in American Government with graduate certificate in \\ Ancient/Classical History from American Public University, United States.
}

Received: December 22, 2017

doi:10.11114/ijsss.v6i2.2935

\author{
Accepted: January 15, 2018 \\ Available online: January 18, 2018 \\ URL: https://doi.org/10.11114/ijsss.v6i2.2935
}

\begin{abstract}
In examination of the constitutional and political institution of the Electoral College the research shows that throughout American politics and history the Electoral College always had and has a role of great political and historical influence. Furthermore the Electoral College has also been a source of much political and constitutional debate. This is an intriguing constitutional needle in a political hay stack for the simple fact that something appears to be insignificant and inconsequential until its time for the national presidential election to roll around every four years. Thus the Electoral College takes front and center of the national political stage as the collective national eyes are all on the presidential race and the ever so magical number of 270. How the Electoral College factors into American politics has been the subject of much political discussion relevant to how the president is elected, how the American public's voice is represented and how democratic of a political institution or representative system is the Electoral College. Through the sands of time of American history there has been camps of voices echoing concerns about the constitutional needle in a political hay stack of the Electoral College and its influential role in American politics.
\end{abstract}

Keywords: Electoral College, 'We the People”, representation, direct popular, national bonus proposal, congressional districts, proportional election

\section{Introduction}

American Politics structurally comprises of a myriad of intricate facets that are at the heart of America's foundation, are constitutionality based and have been the source of great conflict and contention throughout America's political and historical past and present journey. Among some of America's most controversial constitutional doctrine have been, 'Popular severity', 'separation of power', 'checks and balances', the individual powers of each governmental branch. Relevant to states' rights other sources of extensive debate and contention have been how shall 'We the People' be represented, the presidency and the most influential contested and debated facet is the constitutional institution of the Electoral College. Thus in American politics one of the most controversial constitutionally designed components' is the constitutional needle in a political hay stack of the Electoral College; which its influential relevant role and purpose has been called into question as to whether or not it should remain in its current form, be altered or even abolished. Each camp of political thought on the Electoral College has much merit and supported evidence for their perspective cases. In understanding of the political controversy, one must have the ability to come to a conclusion, formulate and create a potential and plausible resolution of this constitutional controversial needle in a hay stack. Moreover there must be consideration and examination of numerous issues relevant to the Electoral College such as; the definition and structure of the Electoral College, the constitutionality of the Electoral College, the constitutional purposes and reasons for the Electoral College, the historical context of the Electoral College. Furthermore one must also consider the past and present examples of controversy surrounding the Electoral College (Presidential Elections of 1800, 1824, 1876, 1888, 1960 and 2000), the proposed arguments of each political position on the Electoral College, the potential solutions for the this constitutional controversy, and the historical influence the Electoral College has had on past and present American politics.

\section{Defining the Constitutional Institution of the Electoral College}

In considering the Electoral College one should first have comprehension of the definition, structure and function of this constitutional institution. The political constitutional institution of the Electoral College was established in the second Article of the Constitution. First it is defined as being a body of electors chosen by the voters in each state to elect the 
President and Vice President of the Untied States. Secondly, the very function of the Electoral College is most evident in the definition of this constitutional institution; the sole constitutional purpose of the design of the Electoral College is involved in the selection process of the president and vice president. Thirdly defined is the form, structure, method and procedure by which the Electoral College achieves its purpose of the selection of America's president and vice president. Through the text presented by Spangler it is explained what is involved in the process of presidential election such as electoral votes are dispersed to a state on the basis of the number of senators and representatives that the state has in Congress. Also each state has two senators and the number of representatives that is determined by the state's population based on the data collected from the national census but it never less than one. Thus, each state has a minimum of three electoral votes. The 1990 census was used for the 1992, 1996 and 2000 presidential elections. (Spangler, 2011)

Furthermore, Spangler goes on to explain that in the election of the president of the U.S. in most states the candidate who obtains the greatest number of popular votes gets all the state's electoral votes or "winner take all". A presidential nominee achieves the presidency by receiving a majority of the electoral votes. Since 1964, when Washington D.C. was added to the Electoral College the total number of electoral votes has been 538; resulting in the golden ticket and magical electoral number sought by presidential candidates is 270. (Spangler, 2011) Monk in her texts goes on to contribute to the examination by explaining that the third part of the presidential selection process by the Electoral College. In the text The Words We Live by authored by Linda R. Monk who stated the following: It it mandatory for the electors to be chosen by federal statue, on the first Tuesday after the first Monday in November is Election Day. Every four years, presidential electors are chosen on that day. Federal law also mandates that the electors cast their own votes for a presidential candidate on the first Monday after the second Wednesday in December. Congress has set January 6 as the date that the electoral votes are totaled before a joint session of Congress.(Monk, 2003) In the defining of the terms, structure and function of the Electoral College one gains insight into the political influential relevance of this Constitutional needle of the Electoral College in the hay stack of American politics.

\section{The Constitutionality of the Electoral College}

In examination of the Electoral College there is a second component that needs to be considered relevant to the constitutionality of the Electoral College. It is in Article II of the Constitution that the foundational base of the Electoral College is found. Article II also articulates the blueprint for the Executive branch, presidency but also the process for which an individual would be selected and elected to the presidency. In section 1, part $2 \& 3$ of Article II there are numerous issues presented relevant to Electoral College. Monk address the first issue presented which is that each State shall appoint, in such way as the Legislature thereof may direct, a number of Electors, equal to the whole number of Senators and Representatives to which the State may be qualified in the Congress: but no Senator or Representative, or person holding an office of trust or profit under the United States, shall be selected an Elector. (Monk, 2003)

Secondly articulated in section 1 of Article II regarding the Electoral College are the procedures that were to be followed during the process of selecting the president. The Electors shall meet in their respective states, and vote by ballot for two Persons, of whom one at least shall not be an inhabitant of the same state with themselves. They shall make a list of all the persons voted for, and of the number of votes for each; which list they shall sign and verify, and transmit sealed to the Seat of the government of the U.S., directed to the President of the Senate. The President of the Senate shall, in the presence of the Senate and House of Representatives, open all the certificates, and the votes shall then be counted. The person having the greatest number of votes shall be the President, if such number be a majority of the whole number of Electors appointed; and if there is more than one who have such majority, and have an equal number of votes, then the House of Representatives shall instantly select by ballot one of them for President; and if no person have a majority, then from the five highest on the list the said House shall in like manner choose the President. Furthermore Monk also discusses that in choosing the President, the votes shall be taken by states, the representatives from each state having one vote; a quorum for this purpose shall consist of a member or members from two thirds of the states, and a majority of all the states shall be required to a choice. In every case, after the choice of the President, the person having the greatest number of votes of the Electors shall be the Vice President. But if there should remain two or more who have equal votes, the Senate shall choose from them by ballot the Vice President. (Monk, 2003) A final contribution by Monk relevant to this matter is that there is a final component connected to the structure and function of the Electoral College found in Section 1 of Article II which is that Congress may determine the time of choosing the Electors, and the Day on which they shall give their votes; which day shall be the same throughout the United States. (Monk, 2003) In consideration of these most specific constitutional requirements for the Electoral College it is most evident that the authority, mandate and obligation afforded to the Electoral College, as controversial as it might be, that is constitutionally founded and grounded. 


\section{The Constitutional Intended Purposes of the Electoral College}

In establishing the definition of the structure of and the constitutional basis of the Electoral College proves most advantageous for an examination and understanding of the Electoral College beginning with the Founding Fathers' intended constitutional purpose of the of Electoral College. America's forefathers worked to create a form and structure of government that would protect American's from tyranny and oppression and also defend the individual freedoms, rights, liberties and true, complete and balanced representation of and for 'We the People'. The constitution institution of the Electoral College would be one of the fundamentally essential products of the work of the founding fathers for protecting equal representation of all Americans and maintaining the checks and balances in the process of electing and selecting the president. In endeavoring to achieve this form of government the architects had two criteria to address. In Nelson's test he discuss the first criteria involving the establishment of a system of government that was fair, noble, good and virtuous. As the founders realized, the problem with a simple distinction between good and bad law is that it is problematic to provide clear benchmarks to differentiate the two in any particular instance. It will not do to submit that in a democracy good legislation imitates the majority will. A majority may tyrannize a minority, violating its rights; and even a non-tyrannical majority may be a imprudent one, favoring polices that do not further its interests. These considerations lay before the Founders' distrust of 'direct' or 'pure' democracy. (Nelson, 2010)

Nelson also goes on toe discuss the second criteria to be grappled with were the potential alternate interpretation of the concept of good or bad legislation. Yet an alternative understanding- that legislation is good if it objectively furthers the limited ends of the polity - is also difficult. It is perhaps impossible to evaluate the 'interests' of a nation without giving substantial consideration to what the citizenry considers its interest to be. This concern lay behind the Founders' animus toward monarchy or aristocracy. Identifying and exemplifying the proper weight to be given popular opinion and its appropriate institutional reflections constitute one of the characteristic problems of democratic constitutionalism. The Founders understanding of republicanism as representative government reveals this problem and the Constitution's attempted solution. (Nelson, 2010) In the forefather's attempt to balance these two criteria's of government it resulted in the creation of the Electoral College among other aspects of America's system and structure of government. Essentially, the Founders attempted to accommodate these two requirements of good government by four devices. Nelson address these two requirements of government by discussing how the architects of America reconciled theses criteria. First, they established the popular election as the fundamental basis of the Constitution and of the government's legitimacy. They adapted that prerequisite by sanctioning 'indirect' selection for some institutions (for example the Senate, Supreme Court, and the presidency) - that is, selection by others who were themselves chosen by the people. In respect to the president, the founders; wanted to provoke the 'sense of the people,; but they feared an incapability to do so if the people acted in a 'collective capacity.' They were apprehensive about the dynamics of mass politics would at best produce poorly competent presidents and at worse open the door to demagoguery and regime instability. At the same time, the Founders; wanted to provide popular opinion a greater role in the selection than it would have if Congress chose the executive. The institutional solution to these concerns was the Electoral College, initially intended as a semiautonomous locus of decisions for presidential selection and chosen by state legislatures at each election.(Nelson, 2010)

\section{The Constitutional Reasons for the Electoral College}

In continual examination of the Electoral College another significant component worth considering is the reasoning behind the purpose of the Electoral College. In further examination of the Electoral College one can observe there being three constitutional reasons for the Electoral College such as; the paramount and essential constitutional doctrine of 'We the People'. Secondly the doctrine and system of republican and democratic representation and the final reason is the constitutional doctrine of checks and balances. Through comprehending the purpose and structure of the Electoral College a correlation can be asserted between the Electoral College and the constitutional doctrine of 'We the People'. For it is the political doctrine and principe of political equality that is found at the very core of democratic theory. In text by Nelson he references Robert Dahl, the leading democratic theorist, includes equality in voting as a central standard for a democratic process. 'Every individual must have a an equal and effective opportunity to vote, and all votes must be counted as equal; Indeed, it is difficult to imagine a definition of democracy that does not include equality in voting as central standard. (Nelson,2010) Furthermore Amar expounds upon Nelson text with his own writing the following; the very roots of the definition of such political ideologies and such as; republic, republican form of government, democracy originates and derives from the people as opposed to aristocracy or monarchy. (The word 'republican' came from the same etymological roots - publica, poplicus - as fundamental and essential as the Preamble word 'People,' whose Greek counterpart, demos, in turn underlying the word democracy.').(Amar, 2005)

The second constitutional based reasoning of the Electoral College is the method of representation that would represent and preserve 'We the People'. The structure of the whole process of how a president of America is to be elected is grounded in the principle of 'equal representation'. In endeavoring to achieve such a goal for Americans the forefathers 
were striving to maintain the delicate balance between the voice of the people being equally represented and the necessity of a political institution, such as the Electoral College, to be the check to ensure the balance was preserved between large and smaller states. Thus the majority and minority of political voices and interests were preserved equally in representation of one voice, one vote. Authors Karp and Feld discuss the third constitutional reason for the Electoral College the constitutional doctrine of checks and balances. The constitutional design and reasoning of the Electoral College was mirrored by the founding fathers's comprise in the design of the Constitution to balance the interests of small and large states by creating a bicameral Congress, with representation based on states in the senate and population in the house, and reform of presidential elections must balance the interests of small-and large-populated states.(Karp \& Tolber, 2010) This was just as true for the Electoral College; the president was voted by the popular vote but selected by the Electoral College to maintain the balance of the political interests and voices of the large states and the small states alike. Cain explains the importance of maintaining the balance between the large and small states. During the early days of American politics though it may have only been 13 states but would grew to 50 states, there was varying sizes among the states and the people's political needs, voices and interests that were to be equally represented. The intricate system was a consequence of the political position faced by the founders. The nation was composed of 13 states of varying populations' sizes and geographical expanses comprising of only 4 million people scattered across thousands of miles loosely connected by transportation and communication. Numerous proposals including direct popular vote and selection by the state legislatures or by Congress were considered by the Constitutional convention but were rejected. (Cain, 2007)

\section{The Historical Context and Framework of the Electoral College}

Progressing forward though the examination of the constitutional institution of the Electoral College much consideration should be given to the historical framework and context of the Electoral College causing past political and constitutional conflicts as well as potential future Electoral College controversies. Milkis \& Nelson in his text discusses the historical backdrop as to how the design of the Electoral College came to be in political existence. Embarking on this problematic process of the election of the president and representation of the people that the founders had to confront on September 4, the Committee on Postponed Matters, chaired by David Brearley of New Jersey, numerous recommendations about the presidency. The committee occasionally referred to as the Committee on Unfinished Parts or, because it had one member from each state delegation at the convention, the Committee of Eleven, proposed a president term of four years rather than seven, with no limitations on the president's eligibility for reappointment. The president was to be chosen by an electoral college, not by Congress. In the design of the Electoral College, each state would select, by whatever methods it chose, electors equal in number to its representatives and senators in Congress. The candidate, who received the greatest number of electoral votes, assuming the support of a majority of electors, would become president. The candidate that finished second would become vice president. (This was the first mention of the vice presidency at the convention.) If no candidate received a majority, the Senate would select the president and vice president from among the five candidates who received the greatest number of electoral votes. (Milkis, \& Nelson 2007)

Although the forefathers came up with a proposal to this problematic process it did not come without ironic inadequateness and insufficiencies. Milkis \& Nelson discusses more the troublesome process for the Electoral College. The The source of the irony was the convention's faulty assumptions that political parties would not arise to contest presidential elections. Instead, the representatives believed that states and ad-hoc groups would nominate contenders for president. Individual electors would then vote for two of these candidates, one of them perhaps a local favorite but the other a leader of national nature. The utmost esteemed and, presumably, the best-qualified candidate would be elected as president and the second most respected as vice president.(Milkis \& Nelson, 2005) Unfortunately the delegates' expectations were soon disappointed due to there being two political parties that formed during the Washington administration began within a very few years to nominate complete national tickets. Previously noted in 1800 the inevitable happened, with the perverse tie vote in the presidential election between Jefferson and his democratic-Republican running mate, Burr. Thus making matters worse, disgruntled Federalists then began hatching plots for the 1804 election. If the Democratic-Republican ticket won, they resolved, Federalists electors would cast on of their votes for the opposition party's vice-presidential nominee, thereby electing him instead of the presidential nominee as president and the presidential nominee as vice president.(Milkis \& Nelson, 2005) Though the framers of the Constitution and the Electoral College were correct in their solution and the constitutional purpose and reasons behind it; they would be found inaccurate regarding the political matters and concerns that the Founders not only could not anticipate nor did they support such future political players or institutions of political parties or factions.

\section{The Past and Present El ectoral College Controversies}

Through examining the historical context and framework of Electoral College the foundation is laid for insight into how there were past and now present historical controversial cases (Presidential Elections of 1800, 1824, 1876, 1888, 1960 
and 2000) involving the Electoral College. Under the Electoral College system, the victor of the popular vote for president has been defeated at minimum four - and potentially five- times or more (Monk, 2003) In the first two Electoral College controversies that arose were the presidential elections of 1800 and 1824. Monk examines the role of political parties relevant to the Electoral College. Political parties rapidly engulfed the nominating process for presidential candidates, and the Electoral College most frequently determined the victor of the election. In fact, the House of Representatives selected the president only twice: in 1800 and 1824. The founders' vision of an independent body of electors swiftly vanished. Political parties offered their own slate of electors in the popular election, pledged to vote for the party's candidate. Seldom, a 'faithless elector' did not vote as the party instructed, and numerous states enacted laws binding an elector to the result of the popular vote. The constitutionality of such laws remains unclear, but the Supreme Court has ruled that political parties may require loyalty pledges from potential electors. Today most states do not even list the names of the electors on their presidential ballots,(Monk, 2003) In gaining knowledge of the evolution of American politics it becomes evident the necessity in giving close consideration and examination to the historical examples of controversy involving the Electoral College.

\subsection{The Presidential Elections of 1800 and 1824}

The first controversial historical example involving the Electoral College involved the presidential election of 1800 . Monk explores the first Electoral College controversy in great detail. In 1800 two candidates were offered by both political parties, but because the electoral vote did not distinguish between president and vice president, the result was a tie. Thomas Jefferson and his running mate, Aaron Burr, received the same number of electoral votes, necessitating the House of Representatives to select the president. Moreover, Burr refused to remove himself from consideration, and after 36 ballots the House elected Jefferson - only two weeks before his inauguration.(Monk, 2003) Moreover Monk also explains the issues in the second controversy related to the Electoral College. Fast forwarding through history to the 1824 election Andrew Jackson received the plurality of popular votes but not a majority of the Electoral College. The House of Representatives then selected as president John Quincy Adams, who placed second in the popular vote. Although, in some states not all the candidates appeared on the ballots, and in numerous states there was no popular vote because the legislature chose the electors.(Monk, 2003) Through these historical examples of two presidential elections America has seen the first indicators of how electing of the president could be taken out of their hands and potentially the political interests and voices of 'We the People' were unrepresented and fell on political deaf ears; thus also bringing to light the political inadequacies and controversies in the constitutional institution of the Electoral College.

\subsection{The Presidential Election of 1876}

Thirdly the presidential election of 1876 presented America with another Electoral College controversy. For the constitution did not give specifications as to how to address instances of contested Electoral College votes. Thus, in 1876, four states submitted two sets of Electoral College votes, and Congress established an Electoral College commission to determine which votes should be counted. Democrat Samuel Tiden who had defeated Republican Rutherford B. Hayes in the popular vote and was only one electoral vote short of victory, but the electoral commission awarded all four contested states to Hayes. Congress pacified southern Democrats by promising to end Reconstruction. Following the examination of these two political controversies Monk goes on to explain the fallout from these elections. The political ramifications following the 1876 presidential election controversy involved Congress establishing procedures for challenging electoral votes. Under the new procedural system, states that had certified electors by December 12 would have a 'safe harbor' against challenge, unless both houses of Congress agreed to the challenge. This newly imposed deadline by Congress for the Electoral College would become most crucial and significant in future presidential elections such as in 2000 where the Supreme Court in Bush v. Gore (2000) refused to mandate a manual (by hand) recount of the Florida presidential ballots. Nonetheless, many other states did not certify their electors by that date in the 2000 election. (Monk, 2003).

\subsection{The Presidential Election of 1888 and 1960}

Once more fast forwarding to the presidential elections of 1888 and 1960 America would experience additional controversial presidential elections. Once again Monk contributes to the understand and examination of the future Electoral College controversies to come. In 1888, President Grover Cleveland achieved victory in the popular vote, but was defeated in the Electoral College by Benjamin Harrison. Cleveland was elected again in 1892, becoming the only president to serve inconsequential terms. In 1960, JFK won the Electoral College by a wide margin, but contingent on how Alabama's electors are credited a slate of eleven uncommitted Democratic electors in 1960, only five of whom voted for Kennedy. Thus if those electors had been prorated, then Richard Nixon would have won the popular vote by one-tenth of one percent. (Monk,2003) Once again it can be observed with the 1960 presidential election two themes that had either occurred in the past or again would be a political issue in a future election of 2000. The election of 1960 
demonstrated to the American people how the people's voice and interest would be represented was once more contingent on the Electors.

\subsection{The Presidential Election of 2000}

The final example of controversy relevant to the Electoral College comes form more recent pages and in American politics and history regarding the 2000 presidential election between Bush and Gore. Author Spangler, accordingly wrote, that it has been a year passed since America has experienced the very close U.S. presidential election in 2000. For the fourth time in U.S. history, a president was elected without achieving a majority of the popular vote. (Spangler, 2011) Also Greenstein address the ramifications of the 2000 election. The political and electoral consequences of the 2000 election was inconclusive Gore had a slight lead in both popular and electoral votes, but the margin in the key state of Florida was so close that a recount was compulsory. Nonetheless, the recount became deadlocked and entangled in controversies over the validity of the balloting in particular localities. After 36 days, the stalemate was broken by a judicial ruling of the United States Supreme Court, thus handing down the conclusion of awarding Bush the state's 25 electoral votes and hence the presidency.(Greenstein, 2009)

Furthermore, the ballots from the 2000 election revealed a rare political and historical episode involving contention between 'big states' and 'small states' that had been feared by the framers of the Constitution. Gore nearly won because he carried six of the nine largest states, an advantage of 165 to 78, while Bush carried 13 of the 19 smallest, a 54-23 lead. The Texan's dominance in these small states exactly remunerated for his loss of the single largest state, California. Even though he accounted a million fewer votes than Gore had as well as smaller plurality in the joint totals of these states, the inherent tilt of the Electoral College toward the smaller states brought a draw in this particular matchup. (Pomper, 2001) Moreover Milkis explains that the ballots of the 2000 election became a significant and principal issue of the election for discerning the intent of the voters that had imperfectly marked their ballots. Thus this was most problematic and the fundamental subject of the Supreme Court decision. A seven-justice majority ruled that the counting of every 'under-vote' (that is, every ballot for which a machine had failed to register a vote for president), was unconstitutional. In failing to establish a uniform standard that every county in the state would use to judge the voter's intention, the Florida court had violated the 14th Amendment's obligation that states protect the right of individuals to the 'equal protection of the laws.'(Milkis, 2007)

The decision in judicial case of Bush v. Gore, as discussed by Abadinsky, would be the Court's most controversial opinion for it considered the presidential contest of 2000; which the five-member majority effectively ended the controversial presidential contest by overruling the Florida Supreme Court and refusing to permit any further counting of disputed ballots, many, if not most, of which were from largely African-American election districts (Bush v. Gore). The basis of the Court's ruling was founded in the 'equal protection' clause of the 14th Amendment that, as noted earlier, was enacted to aid blacks in the post-Civil War south. Paradoxically, use of the 14th Amendment by the Warren Court in the 1960's had been criticized by political conservatives as an all -purpose tool for judicial activism. (Abadinsky, 2008) Furthermore the the Bush v Gore case is expounded on by Milkis and Nelson. Thus as a consequence of the Supreme Court decision and the election of 2000 that concluded in a virtual tie, with the gridlock ultimately determined by the Supreme Court. In summary of the Bush v. Gore presidential campaign it was seen as less decisive than the Bush v. Gore Supreme Court case. As a result of the numerous features of the election and the case it caused for the election process to be prolonged and extended, bitter legal dispute that lasted for five weeks after the voters cast their ballots resembled the institutional clashes that had dominated the final third of the 20th century, culminating in the Clinton impeachment. These clashes raised doubts about whether a country that historically had determined the majority of its political conflicts through the electoral process had grown accustomed to institutional contest instead. (Milkis, 2007)

Moreover in the presidential election of 2000 this would be present but additionally would be the political issue of how votes were to be interpreted would directly affect the outcome on another presidential election. The 2000 presidential election stands to be the best as a paradox, at worst as a scandal, of American democracy. Democrat, Al Gore won the greatest votes, a half million more than his Republican adversary George W. Bush, but lost the electoral college by a count of 271 -267. There still was much suspiciousness with this count that was contingent on the total in Florida, where numerous minority votes were deprived of the vote, ballots were perplexing, and recounts were mishandled and manipulated. The choice of their leader came not from the citizens of the nation, but from attorneys fighting for five weeks. The concluding result was made not by 105 million voters, but by a 5-4 majority of the unelected U.S. Supreme Court, rendering a tainted and partisan verdict.(Pomper, 2001) Considering the controversial election of 2000 and all that was involved if nothing else came out of it and that was most evident was the fundamental concern for the American public, 'We the people' the collective of the individual Americans who deserve the constitutional right to vote for president. We do not have it now. Last year's presidential election demonstrated that our Constitution ought be amended to state explicitly that every citizen of mandatory age has a constitutional right to vote for the presidential 
electors and that the popular vote in each state determines the allocation of Electoral College votes. This type of an amendment would retain the Electoral College voting system of electing the president and not alter the balance of power between large and small states, among regions, or between parties. (Caraley, 2001) Thus ensuring and protecting "We the People" voice being heard, presented and the president would be elected by the American citizenry, 'We the People.'

\subsection{Future Potential Electoral College Controversies}

In the extensive consideration of the past controversies involving the Electoral College in 2016 there was much debate and speculation as to whether or not there would be future instances of controversies involving the Electoral College. The answer to this political question will only be known in time although relevant to the current political climate of 2016 and events there was good plausible reasoning to think that in the 2016 presidential election could presented another controversy over the Electoral College. Starting in January of 2016 throughout the Democratic and Republican primaries alike there had been cases where republican and democratic primary delegates casted their votes for specific presidential candidates and then the casted delegate votes seem to be changed or altered. More specifically with the democratic primaries the delegates had been casted for Sanders by democratic voters and delegates but the super delegates in the same state gave it to Clinton. Also on the republican side during the Louisiana primary on March 5, 2016 Trump was the victor but after the fact Trump did not maintain those 25 delegates. Those circumstances gave much evidence of the delegates conducting themselves in a contrary manner during the primaries gave substantial evidence to a potential controversy and political concern over the 2016 presidential election.

Although primary delegates are different from Electoral College delegates the current political climate of 2016 still leaded itself to provide evidence that there was potentiality for an Electoral College controversy. The 2016 presidential election there had been immense and extensive political division and conflict thus giving cause to wonder if this type of political environment and dynamics would influence the popular vote and also have political consequences relevant to the Electoral College in November of 2016. Potentially resulting in various states being divided as to how the delegates of the Electoral College should vote and thus potentially resulting in the delegates casting their votes in opposition of the popular vote of that state in the 2016 election. Thus ultimately resulting the collective Electoral College vote being cast and being given to the presidential candidate not voted for by the popular vote thus resulting in another contested presidential election such as in 2000. There was much concern that if had been the political reality and outcome of the 2016 election then America would have once more been faced with another Electoral College controversy. If the 2016 election had resulted in this political event 'We the People' will once again wrestled and debated the merits of the constitutional institution of the Electoral College and whether or not to abolish it, amend it or preserve it and only the collective voices of 'We the People' would and will decide the constitutional fate of the Elect oral College.

\section{To Keep or Not to Keep the Constitutional Institution of the Electoral College}

Throughout this most extensive and expansive examination of the Electoral College there is much evidence found to present a case for the controversial and problematic questions, issues and concerns surrounding constitutional institution of the Electoral College. The evidence presented has been found in the examination of the constitutionality of and the influential role of the Electoral College. In the examination of these matters regarding the Electoral College it reasonable to ascertain the potentiality of future controversies involving this constitutional institution thus arguably there is much merit and necessity to finding or creating a solution to prevent and resolve such future constitutional and political controversies relevant to the Electoral College. Throughout the years of American politics there have been multiple suggestions, attempts and proposals presented whether such suggestions or proposals presented the potential solutions of abolishment, uphold the current from the Electoral College or to amend the Electoral College. Amar in his text theorizes as to how or what it will take for a resolution of the Electoral College to come about. If modern Americans were to spend more time evaluating or considering our disavowed constitutional past, perhaps we might comprehend more completely and fully our constitutional present and better envision our constitutional future. Take the Electoral College, the very presence of a Presidential Selection Amendment separated and detached from the original Executive Article demands consideration to the Philadelphia framers' now -superseded presidential system. The original system failed to anticipate the rise of national political parties and consequently rapidly needed to be replaced. This fact alone might prompt us to ask, 'What other significant developments correlated to presidential elections or anything else - did the Philadelphia Founders fail to anticipate? Are there perhaps other mending jobs that need to be done by the American people today? (Amar, 2005)

\subsection{Arguments for the Political and Constitutional Continuation of the Electoral College}

In the midst of all the controversy involving the constitutional and political institution of the Electoral College one can hear echoes of political voices that express their position as advocates of the Electoral College. The defenders of the Electoral College have much relevant evidence and merit that is the foundation of their case for one reason the 
constitutionality of the Electoral College is on their side and in favor of their position for advocating for the Electoral College. Furthermore, it can be argued that with the establishment of the Electoral College the scale of representation of Americans weighs more towards equality and works towards preserving the constitutional doctrine of equal representation and the political principle of one voice, one vote. Thirdly, the proponents of the Electoral College contend that the Electoral College has grown, progressed and advanced to play new and useful roles. Grofman \& Feld, 2005)

\subsection{Arguments for the Abolishment of the Political and Constitutional Institution of the Electoral College}

Equal to the proponents of the Electoral College who have much merit and relevant evidence for their position so do the political voices that echoes disgruntle opposition to the constitutional and political institution of the Electoral College. The opposition presents numerous and diverse arguments in opposition of the Electoral College. The founding fathers of the United States never envisioned the Electoral College to be a perfectly democratic system. Thus some articulated a fear of the tyranny of the majority, and electors were often chosen by state legislators in early presidential elections in the United States, As the system was not purposed to be completely democratic, it is not surprising that some academics have proposed that the current system in the United States may not be optimum. (Hummel, 2011) Similarly, those who wish to eliminate or significantly modify the Electoral College, generally begin by noting that the original rationalization for its existence, the designation of sets of knowledgeable individuals who will meet in isolation in their respective states to deliberate and to make educated choices, has zero relevance to the modern world. Adversaries also frequently point to two key problems: the failure of the Electoral College to fulfill the 'one person, one vote' standard because of it is overwhelming of the seat shares of the smallest states and the potential for the victor of the Electoral College majority to be a popular vote looser. Also contented is that it has been argued that one party may develop a 'built-in' advantage in the Electoral College if its strength comes disproportionately from the smaller states. (Grofman $\&$ Feld, 2005)

A second argument presented by the opponents of the Electoral College is that the Electoral College has been criticized in the past as a failure of our governmental system. Critics contend that the Electoral College 'ignores' the wishes of the people by employing the rule or 'winner-takes-all' award of electoral votes per state and produces 'unfair' results by violating the 'one person, one vote' principle. Maine and Nebraska are the only two states that vary from the unit rule in their selections as two electors are chosen by the statewide vote with the remainder selected by popular vote within congressional districts. (Cain, 2007) A third contention of the adversaries of the Electoral College echoes George Edwards, which puts forth that the Electoral College is essentially at odds with the principles of political equality and majority rule. Edwards makes the case that the Electoral College may be unique as an instrument to select a chief executive, but its sustained existence can no longer be warranted, in large part because the mechanism of the electoral college at innumerable points through its operation can defy the will of the people. (Madonna, 2005)

The fourth piece of evidence presented by the adversaries of the Electoral College states that there are numerous political scientists and news commentators who have criticized the Electoral College for inserting a measure of uncertainty into electoral politics: it is certainly a potential for a second -place finisher in the popular vote to win the electoral college (witness the contest in 2000); American voters do not select the president, only slates of electors who have no formal responsibility, only an ethical obligation, to adhere to the wishes of the citizens of their states; and voters living outside of key battle ground states may have less access to information about the campaigns, and subsequently may be less likely to participate. (Charmock, McCann \& Tenpas, 2009) Furthermore, a fifth contention submitted by the opponents of the Electoral College interjects further that a pair of increasingly heard intertwined arguments against the Electoral College are that the Electoral College emphases attention only on candidates in a relative hand full of potentially competitive states thus leaving much of the nation hardly aware that a presidential election is even going on. Thus reducing overall incentives for turnout, and that it unduly raises the importance of issues that are of concern to voters in the competitive states in contrast to the issues of concerns to voters whose states are not 'in play.' A sixth argument that is levied against the present Electoral College arrangement is that since we might expect that the outcome in the most competitive states will be more competitive than the national popular vote outcome, and since the result of a close election in even a single (large) state may be decided in the Electoral College, the incentives for practicing electoral fraud in such states are considerable.(Grofman \& Feld, 2005)

A final argument that is heard from adversaries of the Electoral College is that their charges include that a 'minority' president can result from the system, the risk of 'faithless' electors is very present and the system decreases voter turnout. Thus the system fails to reflect the national popular vote and the apprehension is that the election will be cas $t$ into the House of Representatives. In political expectation the rally cries often come in times following closely contested elections. (Cain, 2007) Thus giving considerable and extensive attention to the differing camps and political voice's position on the Electoral College one might certainly conclude that, at least what would be political music to the ears of the adversaries of the Electoral College, the most obvious change would be to abolish the Electoral College 
altogether and elect the president by direct popular vote. In 2000 the result would have had a narrow Gore victory. Realistically, this change is unlikely to pass the problematic obstructions to the constitutional amendment process since the president system works to the advantage of small states, which would thwart an amendment from passing the Senate or state legislatures. (Pomper, 2001)

\subsection{Arguments for the Alterations and Amending of the Political and Constitutional Institution of the Electoral College}

In the third camp of political voices regarding the Electoral College, echo and articulate their political position being that yes keep the Electoral College but with the constitutional and political institution undergoing modification and being amended. Arguably it could be said that this position on the Electoral College has the most substantial, extensive and significant merit and evidence to make their case for the alterations or amending Electoral College. Thus this is the case for numerous reasons for one thing there is immense and immeasurable evidence of the original design of the Electoral College being problematic. Secondly, there are six examples of past and present presidential elections (1800, 1824, 1876, 1888, 1960 and 2000) where there was much contention and controversy involving the Electoral College that have brought numerous constitutional concerns and questions regarding the Electoral College. Thus as a direct result the ramification and consequence of such a controversy is there have been over 700 proposals presented before Congress to reform or eliminate the Electoral College more than on any other subject. (Cain, 2007) Thirdly, and arguably the strongest or significant evidence for amending the Electoral College is that there is constitutional precedent already established with the $12^{\text {th }}$ Amendment's ratification in 1804 .

In the text by Milkis and Nelson the authors discuss the backdrop for setting the stage for the constitutional development of the 12th Amendment. Knowing the inappropriateness of the original Constitutional's presidential election process to the new realities of party politics and of the Federalists' inclination to continue to exploit the process's weakness, the Democratic-Republican-controlled Congress voted in December 1803 to recommend the 12th Amendment. Except for Massachusetts, Connecticut and Delaware, the most passionate Federalists states, swiftly ratified (no amendment except the 26th which in 1971 gave 18 year-old the right to vote, has been ratified as rapidly), and the 12th Amendment become part of the Constitution in late 1804, just in time for the presidential election.(Milkis \& Nelson, 2007) Furthermore Monk ways in on this discussion with the contributions from her text related to the 12th Amendment. In accordance with the provisions of the 12th Amendment, the House of Representatives choses among the top three candidates for president if no candidate had a majority in the Electoral College. The Senate shall choose among the top two candidates for vice president, if no candidate for that office has a majority in the Electoral College. Also section 4 permits Congress to stipulate what to do if any of those candidates dies between the meeting of the Electoral College in December and the counting of the electoral votes in Congress on January 6. (Monk, 2003) Furthermore additionally Milkis and Nelson states that the 12 Amendment extended the Constitution's age, residency, and citizenship requirements for the president and the vice president correcting an oversight in the original document. Lastly, the new amendment specified that if a vice president, but not a president, had been chosen by the March 4 following election 'the vice president shall act as President as in the case of the death or other constitutional disability of the President'.(Milkis, 2007) Thus establishing this constitutional precedent of the $12^{\text {th }}$ Amendment makes the potentiality for the further altering or amending of the Electoral College much more conceivable and probable in the future hence making the ability to enact a solution to the problematic Electoral College more accessible or realistic.

\section{Conditionally, the Electoral College is to be Kept Provided It Is Amended}

Through one's extensive examination of the relevant material to the constitutional needle in the political hay stack of the Electoral College, to include the arguments proposed equally by the advocates and opposers of the Electoral College, one can understand and see why hypothetically speaking there would need to be a proposed solutions to address the problematic and controversial political institution of the Electoral College. Arguably there is much evidence and reasons for this hypothetical political scenario that could become a political reality. Thus should this hypothetical become a political actuality it is also understandable the need to consider and address the numerous potential proposed solutions for amending or altering the problematic and controversial Electoral College. Moreover, the right potential proposal for alternating or amending of the Electoral College can only be derived by understanding all the potential proposals such as; the 'direct popular election'/'the automatic proposal', 'the national bonus', 'Congressional districts' and 'proportional electoral voting proposal'. In 'Why is the Electoral College bad for America',

\subsection{Direct Popular Election/Automatic Proposal}

In the current form, structure and method of the Electoral College, as discussed and examined in earlier sections of this research, the Electoral is made up of 538 votes (comprised of 435 votes for members of House of Representatives, 100 Senators and 3 for the District of Columbia /Washington D.C. based on national census taken every 10 years) that are divided in half and plus 1 to account for a potential tie equals to the magic number of 270 . The political reality of this is that with the exceptions to this being Nebraska and Maine each state in the union grants or distributes all of the the 
state's electoral votes the the majority presidential candidate winner in the popular vote which give the present form of the 'Winner takes all' system. There are many echoes by the voices of the opponents to the Electoral College that take issue with this current system, for this current system sets the stage for potentially a handful of states deciding the election for the whole of 'We the People'. The result of these valid concern there have been four proposed potentially viable and better representation of the voices of 'We the People' In the next four sections there will be examination given to theses potential resolution to the constitutional controversy of the Electoral College.

The first proposed potential solution to the current Electoral College system is the direct popular election/automatic proposal. Subsequently after most presidential elections there are calls for the passage of a constitutional amendment to adapt the state-wide winner-take-all feature of the Electoral College currently implemented in all but two states. The two most frequently proposal solutions are to either replace the Electoral College with a direct popular elections or to have the Electoral College seats allocated at the level of House districts with to two bonus seats to the state wide winner - the rule now in place in Nebraska and Maine. (Weber, 2007) In this system of 'Direct popular election' presidential campaigns would focus on more states than just the undecided voters in the battleground states. Moreover, it would renew party competition and spur activities to turn out voters in states that traditionally have not be competitive. (Grofman \& Feld, 2005) Also, with George W. Bush's ability to win the 2000 presidential election without winning the popular vote bolstered calls for abolishing the Electoral College. In 2004, Bush very nearly lost the Electoral College (if 60,000 vote had swung to John Kerry in Ohio) while winning the popular vote. Such ne ar misses have been curiously common and may explain why voluminous citizens are disgruntled with the Electoral College. Recently, journalists have joined the chorus of dissatisfaction with numerous individuals embracing a proposal to reform the Electoral College by persuading the state legislatures to pass laws binding the delegations of Electoral College to the national popular vote. In their articles endorsing the proposal, journalists have cited a number of reasons for their support, but one reason continually appears: that the Electoral College' 'focuses on just a handful of battleground states, and thrusts the rest of the nation's votes to the sidelines. (Madonna, 2005)

If this proposed system of 'Direct popular election' was to be adopted or implemented in the election of presidents, however, this new system would have its own problems. In a close election such as 2000 , recounts would assuredly be demanded throughout the nation. Evident in the 2000 election and Florida's awkward election administration is not unique to Floridal; flaws exist in every state and county. A difference of only a hundred votes per county-as little as one vote in every other precinct-would have reversed the results of 2000. A national recount would mean that the extended delays already experienced in the one state would be replicated everywhere, making it doubtful that Americans would have a president clearly accepted in time for the inauguration. (Lipsiz, 2009) Regardless of the advantages of the 'Direct popular election' there is a significant drawback which is a major cautionary reason for this potential proposed to be the applied as the amended or altered solution to the Electoral College. This potential resolution would put the sole power to elect the president in hands of the few in the larger states. This concern of the right balance of fair, right, just and complete representation between the big and small states was a the center of much concern and debate with the founding fathers. Thus with this potentially proposed solution of the 'Direct Popular election' the question would have to be asked if this was to be the solution for the Electoral College; does 'Direct popular election reach and achieve the desired constitution objective of genuine, fair, equal, comprehensive and true representation of the voices of "We the People"?

\subsection{The National Bonus Proposal}

A second proposed potential solution to the Electoral College system currently in place is the national bonus proposal. If this potential solution was employed to resolve the Electoral College dilemma there would be awarded bonus or extra electoral votes to the winner of the popular election. Proponents of this 'national bonus' plan argue that it preserves the role of small states and thus a more plausible, realistic and practical solution, compared to the "direct popular election", to become a constitutional amendment. Such amendments must be approved by three-fourths of the states, and small states would probably block ratification of an amendment to abolish the Electoral College entirely. Indeed, reform of the Electoral College has been the most frequently proposed constitutional amendment, but it has never received the necessary two-thirds majority to pass Congress and then be submitted to the states for ratification. (Pomper, 2011) Under this potential presidential selection system a question should be asked; as to whether or not would this system of awarding two bonus votes for the winner of the popular vote in the states be constitutionally unfounded and in violation of the constitutional stipulations of how states assign or allocate its electoral votes. Though this is currently the method for two states Nebraska and Maine as in accordance with the $10^{\mathrm{h}}$ Amendment anything not prescribed or stipulated in the Constitution all other matters or issues of concern are left up to the sovereignty of the states. The question is how would this be enacted and implemented in the states would it be an automatic implementation for all other states upon the adoption of this proposal. On the other hand would each state have to amend their own individual state constitutions. Another thought is would in the adoption of the proposal would there automatically be a contingency adopted to 
account for the necessity to have this provision implemented to allow for the allocation of those additional votes. Contingent on the answer to these questions it very well could influence how plausible, realistic and practical the national bonus proposal is and thus impact the odds of this proposal being adopted as the altered or amended form of the Electoral College system.

\subsection{Congressional Districts Proposal}

The proposed potential solution of 'Congressional districts proposal' is the third solution that is presented as a possible resolution to the current form of the Electoral College. This is a commonly heard proposal for amending and modifying the Electoral College. Thus the 'Congressional districts proposal' would alter the methods of choosing the electors within the individual states, which could be accomplished simply through state legislatures without amending the constitution. Imitating the system presently used in Maine and Nebraska, one elector could be awarded to the leading presidential candidate in each congressional district (corresponding to the members of the house), and two (corresponding to the state's senators) could be awarded to the statewide winner. One immediate effect would be to extend the partisanship of congressional redistricting, known as gerrymandering to the presidential election.(Monk, 2003) This practice is already established in Nebraska and Maine which both allow individual districts in their states independently to decide how to allocate electoral votes. As a result these states do not necessarily need to allocate their electoral votes in closer proportion to the number of votes received by the two candidates. For example, in the 2008 U.S. presidential election, Nebraska cast four electoral votes for Republican candidate McCain and one electoral vote for democratic candidate Obama. This resulted in the two candidates receiving electoral votes from Nebraska in closer proportional to the relative to the number of voters that voted for the two candidates in Nebraska. (Pomper, 2011)

Furthermore, some Democrats suggest the election of electors by districts, rather than by the general ticket, is a method that could accomplish results virtually comparable to those of a proportional vote system without requiring a constitutional amendment process or congressional approval; each state's legislatures could enact the necessary laws. The 1890 elections, which brought a widespread reaction against republicans control because of political, economic, and cultural issues, gave democrats their opportunity. (Hummel, 2011) Consequently, in 2000 the result of this system would probably be a clear Bush victory, despite his minority in the country. Assuming the presidential vote had followed that for the House, Bush would won 222 votes from the individual congressional districts where Republicans won House seats, and he would add 60 votes form the 30 states he had captured. This total of 282 votes would be an even greater distortion of the popular vote than the actual results in the election. (Argersinger, 2004.) Considering this proposed solution is already practiced and enacted in two states, Nebraska and Maine, should it be adopted it might be more plausible for it to be readily accepted as a sanctioned solution and ratified by and for the Americans.

\subsection{Proportional Electoral Voting Proposal}

Fourthly, a final proposed solution is presented to the currently operating Electoral College system is the 'proportional electoral voting proposal'. In this final and alternative proposal a states' electoral votes would be allocated and divided proportionally in accordance to match the proportional division of the popular vote in each state, as opposed to the current awarding system of the votes of the winner-takes-all system. In 2000 the president election electoral vote count: Bush would have received 262.6 electoral votes, Gore 214 and Nader 13.6. The proportional system would have made Bush the president with neither a majority nor a plurality of the popular vote. (Pomper, 2001) Through awarding the electoral votes being allocated proportionally, all citizens would get equal consideration. The issues that are important to Texans will be just as important as issues to Ohioans. Federal Policy will be less likely to pander to swing states. If the majority mandate is replaced with a plurality, independents can run as a viable candidate. To compensate, there will have to be a run-off election of the two candidates who receive the most votes. Also if the two-party system was less of a factor in elections, more independent candidates potentially would run, diversifying voter choices. The plurality mandate also negates the chance of the House of Representatives declaring who is president.(Pomper, 2001) Consequently, numerous others have argued that proportional representation system would do a superior job of representing the interest of voters, than the winner-takes-all system commonly used in the United States. (Colquitt, 2008) Furthermore should this proposal be the adopted solution to the Electoral College there is the strong probability that numerous other problems that have been involved in the election of the nation's president would potentially be resolved or at least would be greatly minimized such as; voter disenfranchisement, voter fraud and unfair, unequal and in-comprehensive representation of all Americans. Equally, both large and small states interests would be protected and the political interests and voices of 'We the people' would be heard, protected and represented more equally, truthfully and comprehensively. Proportional representation in the electoral voting if adoptive could arguably have the ability to resolve past and present problematic political issues and controversial constitutional predicaments involving the Electoral College.

In consideration of the current system of the Electoral College and all the potential proposals to resolve this 
constitutional and political dilemma, one could arguably conclude that in adopting of the proportional electoral voting system for the Electoral College would be the best, most practical, conceivable, simplest to implement, and the most accessible for most Americans with fewer political or constitutional consequences or ramifications. This is believed for numerous reasons; the advocates and proponents of this solution proclaim that it is the best solution that can up hold fair, equal, and complete representation of the voices of 'We the People' all the while ensuring the protection of political interests for all American regardless, of party affiliation, demographic background, religion, geographical location interests (north, south, east, west and small or large states) among others. Moreover this solution would have the ability to uphold the 'one vote, one person' principle which allows for equal, fair and complete representation principle better than all the other potential proposals. More specifically this is the case if voter fraud was negated or at least minimized. Furthermore with the numerous advantages of this proposed solution it preserves the constitutionality of the Electoral College and also sustains the intended constitutional purpose of the Electoral College of giving equal, true and comprehensive representation of 'We the people'. In the beginning of my research and journey in considering the constitutionality of the Electoral College I was of the position of keeping and preserving the Electoral College in its current form founded on the original intended constitutional design, form and propose. Considering, that I myself am and forever will be a constitutionalist to the core and having gone through this research process however though, I now hold the position that maintaining the existence of the Electoral College should only be the case if the Electoral College under goes modifications and alterations to its current structure, form and system. I would be in agreement with the political voices of the chorus who advocate and are

proponents of the proposal of 'Proportional electoral voting' for the fact that this solution presents the best protection of fair, comprehensive and equal representation of all American's political interests and of the voices which are paramount, fundamental and the sacred cornerstone to the constitutional doctrine of 'We the People'.

\section{The Historical Influence of the Electoral College on American Politics and Hi story}

In consideration of the extensive evaluation and deliberation of the profoundly controversial political needle in a constitutional hay stack, the institution of the Electoral College, it is unmistakable and undeniable that he Electoral College has had political, constitutional and historical consequential influence on the structural system of government, American politics and history. It is impossible for an institution such as the Electoral College with such a fundamentally, profoundly significant and paramount role not to have influence on American politics, government and history. Presidential elections in the United States is decided by the Electoral College system in which different states are allowed to cast a fixed number of votes, and the candidate that obtains the majority of the electoral votes is elected. In these elections, states ordinarily cast all of its electoral votes for the candidate who receives the majority of the votes in that state. There is a vast amount of evidence of the Electoral College's influence on American history, government and politics. This immense evidence derives from components encompassing the following: the constitutionality of the Electoral College, the constitutional intended purpose and reasons for the Electoral College, the historical framework of the Electoral College, the reoccurring historical and constitutional controversial questions. Also contributing to this case of the influence of the Electoral College is the historical past and present influence of the Electoral College, all political positions on the Electoral College, and lastly the potential proposed solutions for the resolution of this constitutional and political controversial institution of the Electoral College. Furthermore, after 229 years of American politics and history American government is still thwarted with unanswered constitutional questions and an unresolved political dilemma involving the Electoral College. Though in more recent political times the presidential election of 2000 provided a modern reminder of this seemingly unresolved dilemma. What remains to be seen at this present time is whether or not there will be a resolution to this influentially problematic and constitutional institution of the Electoral College and if there is what would that solution exactly look like, involve and what would be the effects of that solution on the American political, governmental system and how the voices of "We the people" will be protected and represented.

\section{Conclusion}

In summation of this examination and consideration of the profoundly controversial constitutional and political institution, the Electoral College, a multitude of certain observations have shed significant light and insight on numerous issues relevant to the Electoral College. First and foremost the Electoral College has always had since America's conception an influential purpose, and role in American history, government and politics and quite possibly always will. Although the question remains to what degree or extent, in what structure or form and in which capacity will the Electoral College will take or evolve. Secondly, it is indisputable that this political institution, while its basis is constitutionally grounded, definitely has been most problematic and has caused its fair share of political and historical controversies. Consequentially it has been argued that adopting and implementing a solution has been latent and desperately lacking and yet a imperative political and constitutional necessity. Throughout American history Americ a, with no resolution, Americans has been forced to experience a diverse array of unresolved political problems and 
unans wered constitutional questions that has created a entire multitude of historical ramifications, political implications and constitutional consequences.

Regardless of the potential political, historical and constitutional solution for the controversial dilemma of the Electoral College the solution first and foremost, fundamentally and paramount to anything else must preserve the fair, complete, comprehensive and equality in representation of the political interests and voices of 'We the People'. If any proposed solution cannot accomplish this then it will also fail and Americans are no better off than with the current, problematic and controversial form to the Electoral College. Thirdly, it is the position of this paper, through much extensive research, that arguably the answer to the constitutional question of the Electoral College is to maintain the constitutional institution but the Electoral College must be modified and amended. It is also the position of this paper that the the supporters and advocates of the potential proposed solution of 'Proportional electoral voting' have the strongest and most substantial evidence to make their case for their proposal. Moreover it is also the position of this paper that this potential solution could provide the American voters with the greatest advantages with the least of amount of negatives. The conclusion of the research presented in this paper is through this potential solution, of the 'Proportional electoral voting', would be the best choice of resolution for the preservation of fair, complete and comprehensive representation of the political interests and voices of 'We the People'. The continual preservation of a more truthful, fair, complete and equal representation of American's political interests and voices 'We the People' within the confines of the Electoral College system will only be determined as American history marches on and time will grant opportunities for future generations of Americans, 'We the People' to resolve and answer the question of the Constitutional needle in the political hay stack of the Electoral College.

\section{References}

Abadinsky, H. (2008). Law and Justice: An Introduction to the American Legal System (6th ed.). Upper Saddle River, NJ: Pearson Prentice Hill.

Amar, A. R. (2005). America's Constitution: A biography. New York, NY: Random House.

Argersinger, P. H. (2004, Jan). Electoral Reform and Partisan Jugular. Political Science Quarterly, 119(3), $499-520$. https://doi.org/10.2307/20202393

Cain, C. (2007, Jan). The electoral college: diversification and the election process. Constitutional Political Economy, 21-34. https://doi.org/10.1007/s10602-006-9010-0

Caraley, D. J. (2001). Editor's Opinion: Why Americans deserve constitutional right to vote for the presidential electors. Political Quarterly, 116(1), 1-3. https://doi.org/10.2307/2657817

Charmock, E. J., McCann, J. A., \& Tenpas, K. D. (2009).Presidential Travel from Eisenhower to George W. Bush: An 'Electoral College'. Strategy Political Science Quarterly, 124(2), 323-3339. https://doi.org/10.1002/j.1538-165X.2009.tb00651.X

Colquitt, B. (2008). Electoral College Reform Policy Studies Journal, 36(4), 693-699.

Greenstein, F. I. (2009). The Presidential Difference: Leadership Style from FDR to Barack Obama. (3rd ed.) Princeton, NJ: Princeton University Press.

Grofman, B., \& Feld, S. L. (2005). Thinking about the Political Impacts of the Electoral College. Public Choice, 123, 1-18. https://doi.org/10.1007/s11127-005-3210-4

Hummel, P. (2011). Proportional versus winner-takes-all electoral vote allocations. Public Choice, 148, $381-393$. https://doi.org/10.1007/s11127-010-9660-3

Karp, J. A., \& Tolber, C. J. (2010) Support for Nationalizing Presidential Elections. Presidential Quarterly, 40(4), 771-793. https://doi.org/10.1111/j.1741-5705.2010.03811.X

Lipsiz, K. (2009). The Consequences of Battleground and 'Spectator' State Residency for Political Participation. Political Behavior, 31, 187-209. https://doi.org/10.1007/s11109-008-9068-7

Madonna, T. G. (2005). Why the Electoral College is Bad for America. Presidential Studies Quarterly, 35(2), 411-412. https://doi.org/10.1111/j.0360-4918.2005.257_3.x

Milkis, S. M. (2007). The American President: Origins and Development 1776 - 2007 (5th ed.). Washington D.C: CQ Press.

Monk, L. R. (2003). The Words We Live by: Your annotated guide to the Constitution New York, NY: Stonesong Press.

Nelson, M. A. (2010). The Presidency and the Political System (9th ed.). Washington D.C: CQ Press. 
Pomper, G. M. (2001). The 2000 presidential election: Why Gore Lost. Political Science Quarterly, 116(2), 201-223. https://doi.org/10.2307/798059

Spangler, D. B. (2011). Presidential Playing Field. Mathematics Teaching in the Middle School, 7(3), 157-159.

Weber, G. D. (2007). The Electoral College exacerbates the red-blue dividd and disenfranchise ethnic minorities. American Psychologist, 62(7), 701-703. https://doi.org/10.1037/0003-066X.62.7.701b

\section{Copyrights}

Copyright for this article is retained by the author(s), with first publication rights granted to the journal.

This is an open-access article distributed under the terms and conditions of the Creative Commons Attribution license which permits unrestricted use, distribution, and reproduction in any medium, provided the original work is properly cited. 